\title{
PENGEMBANGAN BAHAN AJAR BERBASIS DIDACTICAL DESIGN RESEARCHYANG BERORIENTASI PENINGKATAN PEDAGOGICAL CONTENT KNOWLEDGE
}

\author{
Mohamad Gilar Jatisunda, Nia Kania \\ Pendidikan Matematika, Universitas Majalengka \\ E-mail g.jatisunda@unma.ac.id
}

\begin{abstract}
Pedagogic competence is the teacher's ability to learn, while professional competence is the teacher's ability to master the knowledge of the sciences they are teaching. A teacher's pedagogical content knowledge can develop well along with his experience in teaching. However, in reality, not all of them provide a good experience for Pedagogical Content Knowledge development. So it is essential to prepare prospective mathematics teachers to have good Pedagogical Content Knowledgedevelopment alternatives. Pedagogical Content Knowledge is to develop teaching materials based on Didactical Design Research, where the teaching materials produced are following student response conditions. To overcome this problem, one effort that can be done is to develop teaching materials through learning that can encourage the development of pedagogical content knowledge. Learning that facilitates this is learning with teaching materials developed based on didactical design research (DDR). This study uses a development research method by adapting the ADDIE model (Analysis, Design, Development, Implementation, and Evaluation). The results showed that the teaching materials developed met valid criteria based on curriculum experts, material experts, and media experts with excellent assessment categories. The teaching materials developed have met the applicable criteria with excellent quality based on teacher and student assessments. Teaching materials are also considered adequate because the math problem-solving ability test results show students' mastery of $89.01 \%$.

Keywords: Didactical Design Research, Pedagogical Content Knowledge, Pre-service Mathematics Teacher
\end{abstract}

\begin{abstract}
ABSTRAK
Kompetensi pedagogik merupakan kemampuan guru dalam pengelolaan pembelajaran sedangkan kompetensi profesional merupakan kemampuan guru dalam menguasai pengetahuan bidang ilmu pengetahuan yang diampunya. Pedagogical Content Knowledge seorang guru dapat berkembang dengan baik seiring dengan pengalamannya dalam mengajar. Namun kenyataannya tidak semua memberikan pengalaman yang baik bagi pengembangan Pedagogical Content Knowledge. Sehingga penting mempersiapkan calon guru matematika mempunyai Pedagogical Content Knowledge yang baik. Alternatif pengembangan. Pedagogical Content Knowledge adalah dengan mengembangkan bahan ajar berbasis Didactical Design Research, dimana bahan ajar yang di hasilkan sesuai dengan kondisi respon mahasiswa. Untuk mengatasi permasalahan tersebut, salah satu upaya yang dapat dilakukan adalah dengan melakukan pengembangan bahan ajar melalui pembelajaran yang dapat mendorong mengembangkan pedagogical content knowledge. Pembelajaran yang memfasilitasi hal tersebut adalah pembelajaran dengan bahan ajar yang dikembangkan berbasis didactical design research (DDR). Penelitian ini menggunakan metode penelitian pengembangan dengan mengadaptasi model ADDIE (Analysis, Design, Development, Implementation, dan Evaluation). Hasil penelitian menunjukkan bahan ajar yang dikembangkan memenuhi kriteria valid berdasarkan ahli kurikulum, ahli materi dan ahli media dengan kategori penilaian sangat baik. Berdasarkan penilaian guru dan siswa, bahan ajar yang dikembangkan telah memenuhi kriteria praktis dengan kualitas sangat baik. Bahan ajar juga dinilai efektif karena hasil tes kemampuan pemecahan masalah matematika menunjukkan ketuntasan siswa sebesar 89,01\%.
\end{abstract}

Kata Kunci: Didactical Design Research, Pedagogical Content Knowledge, Calon Guru Matematika

Submitted Nov 18, 2020 | Revised Nov 30, 2020 | Accepted Des 10, 2020

\section{Pendahuluan}

Matematika merupakan komponen utama kognitif manusia (Ernest, 2015). Penting setiap siswa dibekali mata pelajaran matematika. Pembelajaran matematika dikelas memiliki peran penting dalam memfasilitasi pemerolehan pengetahuan setiap peserta didik (Argyle, 2013). Peran guru menjadi penting agar bisa memfasilitasi hal tersebut. Kompetensi guru matematika merupakan konstruksi 
kompetensi professional dan kompetensi pedagogik (Blömeke et al., 2020). Kompetensi umum seorang guru meliputi: memahami perkembangan berpikir dan perkebangan psikologi siswa, kesadaran proses belajar mengajar, pengelolaan kelas, metode pengajaran, pengendalian dan evaluasi (Ilanlou \& Zand, 2011). Peraturan Pemerintah Nomor 74 Tahun 2008 pasal 3 bahwa seorang guru wajib memiliki kompetensi pedagogik, kompetensi profesional, kompetensi kepribadian, dan kompetensi sosial. Kompetensi pedagogik merupakan kemampuan guru dalam pengelolaan pembelajaran sedangkan kompetensi profesional merupakan kemampuan guru dalam menguasai pengetahuan bidang ilmu pengetahuan yang diampunya.

Proses belajar mengajar merupakan aktivitas yang bersifat kompleks (Maher et al., 2018). Shulman (1987) mengajukan konsep tiga dimensi pengetahuan profesional yang penting bagi guru yaitu Subject Matter Content Knowledge, Pedagogical Content Knowledge, dan Curriculum Knowledge. Pedagogical Content Knowledge merupakan konsep berpikir yang memberikan pengertian bahwa untuk mengajar sains tidak cukup hanya knowing science tetapi juga how to teach (Sukaesih et al., 2017). Beberapa hasil penelitian Shulman menunjukkan bahwa Pengetahuan konten pedagogik merupakan penentu utama keberhasilan guru dalam pembelajaran. Meskipun demikian, pengetahuan konten pedagogik tidak bisa dipisahkan dengan pengetahuan konten dan pengetahuan pedagogic (Herold, 2019). Pengetahuan konten pedagogik merupakan suatu konstruksi akademik yang menggambarkan suatu ide yang dapat membangkitkan minat untuk mempelajari sesuatu (Loughran, 2005). Terdapat tiga pengetahuan yang harus dikuasai guru, yaitu pengetahuan konseptual, pengetahuan tentang struktur materi, dan pengetahuan tentang orientasi konteks spesifik dalam mengajar (Gess-Newsome et al., 2019). Hasil penelitian menunjukkan bahwa Pedagogical Content Knowledge merupakan penentu utama keberhasilan guru pada pembelajaran (Gudmundsdottir \& Shulman, 1987).

Pedagogical Content Knowledge seorang guru dapat berkembang dengan baik seiring dengan pengalamannya dalam mengajar. Namun kenyataannya tidak semua memberikan pengalaman yang baik bagi pengembangan Pedagogical Content (Hannula, 2017). Knowledge.Salah satu faktornya adalah kebiasaan guru dalam melaksanakan proses pembelajaran, strategi digunakan selalu sama untuk semua konsep yang diajarkan dan urutan penyajian konsep yang diajarkan masih terkait dengan urutan penyajian dalam buku paket belum dikembangkan sendiri sesuai dengan kondisi siswa. Sehingga penting mempersiapkan calon guru matematika mempunyai Pedagogical Content Knowledge yang baik. Calon guru matematika sebagai calon tenaga profesional mengandung makna bahwa mereka perlu terus menerus mengembangkan kompetensi profesioanlnya untuk peningkatan kualitas siswa (Subanji, 2015). Dengan pengembangan bahan ajar berbasis Didactical Design Research, memberikan mahasiswa kemudahan untuk menghilangkan hambatan-hambatan pada saat memahami materi yang di ajarkan. karena bahan ajar yang di siapkan sesuai denga lintasan belajar mahasiswa. Pedagogical Content Knowledge merupakan gabungan pengetahuan konten dan pengetahuan pedagogik. Sehingga penting untuk mempersiapkan calon guru matematika dengan baik yang memiliki kemampuan Pedagogical Content Knowledge yang baik. Pada perguruan tinggi calon guru matematika dilatih menjadi guru profesional, baik dari segi penguasaan materi maupun keterampilan mengajar.

Proses pengembangan bahan ajar berbasis Didactical Design Research melalui tiga tahapan yaitu: (1) Analisis situasi didaktis sebelum pembelajaran (prospective analysis) yang wujudnya berupa Desain Didaktis Hipotesis termasuk ADP. (2). Analisis metapedadidaktif, yaitu dengan mengimplementasikan desain didaktis yang telah disusun, menganalisis situasi, respon siswa, dan antisipasi terhadap respon siswa saat desain didaktis diimplementasikan. (3). Analisis restrosfektif (restrospective analysis) yakni analisis yang mengaitkan hasil analisis situasi didaktis hipotesis dengan hasil analisis metapedadidaktik (Suryadi, 2010). Berdasarkan uraian tersebut, tujuan penelitian ini adalah mengembangkan bahan ajar matematika berbasis Didactical Design Research, sebagai upaya peningkatan Pedagogical Content Knowledge pada materi Dimensi Tiga pada perkuliahan Kapita Selekta Tingkat Atas dan untuk mendeskripsikan kualitas desain didaktis yang berorientasi peningkatan Pedagogical Content Knowledge calon guru 
matematika di lihat aspek kevalidan, kepraktisan dan keefektifan. Spesifikasi pengembangan bahan ajar berbasis Didactical Design Research adalah bahan ajar yang memperhatikan respon siswa, dimana pengembangan melalui proses (1) Analisis situasi didaktis (2) Analisis Metapedadiktik (3). Analisis rektrosfektif, dari ketiga proses tersebut didapatkan desain didaktis yang sesuai dengan lintasan belajar mahasiswa.

Tahapan selanjutnya proses berpikir guru sebelum pembelajaran yaitu menganalisis pengetahuan yang terkait dengan siswa, salah satunya adalah learning obstacle siswa (Suryadi, 2013). Situasi didaktis terdiri dari hubungan antara guru, siswa dan materi (Kansanen \& Meri, 1999). Segitiga didaktis tersebut menjadi dasar Analisa untuk perancangan situasi pembelajaran. Analisis learning obstcales merupakan salah satu bagian penting mempersiapkan situasi pembelajaran (Lestarai, 2019). Seringkali ketika terjadi learning obstacle tidak ditindaklanjuti dengan analisis kenapa terjadinya learning obstacle selama proses pembelajaran (Perbowo \& Anjarwati, 2017). Identifikasi learning obstcales penting tidak hanya untuk mengubah situasi pembelajaran saat ini tetapi juga untuk menentukan strategi pembelajaran baru yang difokuskan pada hambatan epistemologis yang diidentifikasi (Clément, 2003). Terdapat tiga jenis learning obstacle, yaitu ontogenic obstacle, didactical obstacle, dan epistemological obstacle (Brousseau, 2006). Tujuan lainnya analisis learning obstacles adalah menciptakan situasi didaktis agar relasi antara siswa dengan materi ajar sehingga dapat menciptakan situasi didaktis yang ideal bagi siswa (Carvalho et al., 2004). Berdasarkan uraian tersebut penelitian ini bertujuan untuk merancang bahan ajar berbasis Didactical Design Research yang berorientasi peningkatan Pedagogical Content Knowledge calon guru matematika.

\section{Metode Penelitian}

Penelitian ini merupakan Research and Development dengan model pengembangan yang digunakan yaitu model ADDIE, meliputi lima tahapan, yaitu Analysis, Design, Development, Implementation, dan Evaluation (Muruganantham, 2015). Produk yang dikembangkan dalam penelitian ini berupa bahan ajar matematika berbasis Didactical Design Research untuk memfasilitasi Pedagogical Content Knowledge calon guru matematika. Beberapa tahapan integrasi Didactical Design Research pada Research and Development model ADDIE:

1. Tahap Analisis (Analysis)

Tahapan analisis learning obstcale bukan murni berasal dari kemampuan siswa saja. Hambatan belajar yang berasal dari faktor perkembangan siswa (ontogenical obstacles), hambatan karena faktor bagaimana pengetahuan itu terbentuk (epistemological obstacles) dan hambatan yang disebabkan oleh pilihan materi pembelajaran yang diambil guru dalam proses pembelajaran (didactical obstacles) (Brousseau, 2006). Analisis yang digunakan untuk melihat learning obstacles yang dialami siswa pada materi pertidaksamaan kuadrat perlu disusun tes pemahaman konsep. Analisis learning obstcale merupakan tahapan awal memasuki proses didactical design research (DDR).

2. Tahap Desain (Design)

Tahap desain dilakukan dengan merancang bahan ajar matematika berbasis pendekatan saintifik. Bahan ajar dirancang dengan pertimbangan beberapa temuan yang diperoleh pada tahapan analisis, diantaranya yaitu peta kebutuhan bahan ajar serta struktur bahan ajar. Dalam tahapan ini juga, dilakukan penyusunan instrumen penelitian, dan validasi instrumen penelitian oleh pakar.

3. Tahap Pengembangan (Development)

Tahap pengembangan merupakan tahap pembuatan bahan ajar matematika berbasis pendekatan saintifik. Bahan ajar yang dikembangkan disesuaikan dengan desain yang telah dirancang sebelumnya. Hal-hal yang dilakukan terlebih dahulu dalam pembuatan bahan ajar yaitu mengumpulkan materi pembelajaran yang akan disajikan, gambar, video, dan animasi yang berkaitan dengan materi. Dengan cara ibi diharapkan menambah ketertarikan siswa dalam belajar 
matematika. Setelah seluruh bahan yang dibutuhkan terkumpul, maka langkah berikutnya yaitu mengembangkan bahan ajar matematika berbasis pendekatan saintifik.

4. Tahap Implementasi (Implementation)

Tahap ini merupakan langkah untuk melakukan uji coba bahan ajar yang telah dikembangkan. Bahan ajar diujicobakan kepada mahasiswa. Tahapan uji coba dilakukan dengan melaksanakan pembelajaran matematika dengan pendekatan saintifik menggunakan bahan ajar yang dikembangkan dan pelaksanaan postes untuk mengukur kemampuan pemecahan masalah matematika siswa setelah melaksanakan pembelajaran.

5. Tahap Evaluasi (Evaluation)

Tahap evaluasi merupakan tahap penilaian terhadap bahan ajar matematika yang dikembangkan. Penilaian dilakukan dengan melihat komponen kelayakan isi, penyajian, bahasa, dan kegrafikan bahan ajar yang dikembangkan. Di samping itu, pada tahap ini dilakukan tes kemampuan pemecahan masalah pada siswa. Tes ini dilakukan untuk melihat efektivitas bahan ajar matematika yang dikembangkan dalam memfasilitasi kemampuan pemecahan masalah matematis siswa.

\section{Hasil dan Pembahasan}

1. Proses Pengembangan Draf Bahan Ajar Berbasis Didactical Design Research (DDR)

Prosedur pengembangan bahan ajar yang digunakan menggunakan teori-teori berdasarkan Didactical Design Research (DDR) yang berorientasi pada pedagogical content knowledge (PCK) calon guru matematika pada materi operasi bilangan pecahan adalah dengan menggunakan model pengembangan ADDIE. Model pengembangan ADDIE terdiri dari lima tahap, yaitu: Analysis, Design, Development, Implementation, dan Evaluation.

a. Tahapan Analysis

Penelitian-penelitian pada tingkat sekolah menengah pertama ataupun sekolah menengah atas siswa mengalami kesulitan ketika mempelajari matematika berpengaruh terhadap kemampuan matematis mereka (Jatisunda, 2019). Begitu juga hal tersebut terjadi pada tingat perguruan tinggi, kemampuan matematis mahasiswa sangat dipengaruhi oleh kemampuan mereka mengahadapi kesulitan ketika mempelajari matematika (Muslim et al., 2017). Kesulitankesulitan tersebut merupakan manifestasi dari hambatan-hambatan yang di alami oleh siswa ketika dihadapkan pada materi ajar. Hambatan-hambatan tersebut bukan murni berasal dari kemampuan siswa saja. Hambatan belajar yang berasal dari faktor perkembangan siswa (ontogenical obstacles), hambatan karena faktor bagaimana pengetahuan itu terbentuk (epistemological obstacles) dan hambatan yang disebabkan oleh pilihan materi pembelajaran yang diambil guru dalam proses pembelajaran (didactical obstacles) (Brousseau, 2006). Analisis yang digunakan untuk melihat learning obstacles yang dialami siswa pada materi pertidaksamaan kuadrat perlu disusun tes pemahaman konsep. Tes ini disusun berdasarkan kompetensi dasar pembelajaran materi pertidaksamaan kuadrat.

b. Tahap Design

Berdasarkan temuan-temuan pada tahapan analisis disusun Hypothetical Learning Trajectories (HLT). HLT merupakan konstruksi proses pembelajaran berdasarkan antisipasi belajar siswa yang didasari oleh tujuan pembelajaran, pengetahuan dan perkiraan tingkat pemahaman siswanya, serta pilihan aktivitas matematika (Conner et al., 2017; Empson, 2011; Fuadiah, 2017). Adapun temuan HLT berdasarkan analisis learning obstacle adalah sebagai berikut: 
T

\begin{tabular}{|c|c|c|}
\hline \multirow{2}{*}{$\begin{array}{l}\text { b } \text { bo. }^{-} \\
\mathbf{e}_{1}\end{array}$} & \multicolumn{2}{|l|}{ Learning Trajectories } \\
\hline & Persamaan kuadrat " $a x^{2}+b x+c=0 "$ & \\
\hline 2 & Fungsi kuadrat " $\mathrm{f}(\mathrm{x})=\mathrm{ax}^{2}+\mathrm{bx}+\mathrm{c} ; \mathrm{f}(\mathrm{x})=(\mathrm{x}+\mathrm{p})(\mathrm{x}-$ & Permasalahan \\
\hline 1 & q); $y=a x^{2}+b x+c "$ & menggambarkan garafik \\
\hline .3 & $\begin{array}{l}\text { Grafik fungsi kuadrat "Domain, range, tebuka ke } \\
\text { atas; terbuka }\end{array}$ & persamaan kuadrat \\
\hline$H$ & ke bawah" & \\
\hline$y^{4}$ & Pertidaksamaan kuadrat & Permasalahan menggambar \\
\hline$p$ & $\mathrm{f}(\mathrm{x})<0 ; \mathrm{f}(\mathrm{x})>0$ & grafik pertidaksamaan \\
\hline 0 & $a x^{2}+b x+c<0 ; a x^{2}+b x+c>0$ & \\
\hline$t$ & $a x^{2}+b x+c<0 ; a x^{2}+b x+c>0$ & \\
\hline$b$ & ada solusi & \\
\hline$e^{5}$ & Pertidaksamaan kuadrat & \\
\hline$t$ & $\mathrm{f}(\mathrm{x}), 0 ; \mathrm{f}(\mathrm{x})>0$ & \\
\hline$i$ & $a x^{2}+b x+c<0 ; a x^{2}+b x+c>0$ & \\
\hline$c$ & solusi untuk semua $\mathrm{x} \in \mathrm{R}$ & \\
\hline$a 6$ & Pertidaksamaan kuadrat & \\
\hline l & $\mathrm{f}(\mathrm{x}), 0 ; \mathrm{f}(\mathrm{x})>0$ & \\
\hline & $a x^{2}+b x+c<0 ; a x^{2}+b x+c>0$ & \\
\hline$L$ & tidak ada solusi $(\mathrm{x} \in \emptyset)$ & \\
\hline $\begin{array}{l}e 7 \\
a\end{array}$ & Solusi aljabar (garis bilangan) pertidaksamaan kuadrat & $\begin{array}{l}\text { Mencari solusi permasalahan } \\
\text { dengan garis bilangan }\end{array}$ \\
\hline
\end{tabular}

Learning trajectories dirancang berdasarkan analisis learning obstacle yang ditemukan sebelumnnya. Pendekatan fungsi dipilih berdasarkan analisis learning obstecle menentukan himpunan penyelesaian pertidaksamaan kuadrat apabila grafik fungsi kuadrat diberikan. Selain itu, pendekatan tunggal (metode garis bilangan) yang digunakan siswa tidak dapat menyelesaikan semua masalah pertidaksamaan kuadrat dan juga membuat siswa hanya memahami secara prosedural saja. Learning obstacles, learning trajectories dan theory didactical situation (TDS) disusun suatu desain didaktis pertidaksamaan kuadrat. Desain ini terdiri atas tiga desain didaktis, setiap desain tersebut memuat satu atau lebih situasi didaktis. Situasi dalam TDS itu terdiri dari situasi-aksi, situasi formulasi dan situasi-validasi dan situasi instutisionalisasi (Brousseau, 2006). Desain didaktis juga disusun berdasarkan respon yang mungkin muncul di pembelajaran. Respon yang muncul bisa sangat beragam, oleh karena itu berdasarkan analisis atas respon yang mungkin muncul disusun pula suatu antisipasi didaktis pedagogis atas respon siswa.

c. Tahapan Development

Hasil dari tahap pengembangan ini berupa draf bahan ajar matematika berbasis didactical design research untuk memfasilitasi pengembangan pedagogical content knowledge (PCK). Learning Obstacles, Learning Trajectories dan didasarkan atas Teori Situasi Didaktis disusun suatu desain didaktis pertidaksamaan kuadrat. TDS terdiri dari situasi-aksi, situasi-formulasi dan situasi-validasi oleh karena itu setiap situasi disusun berdasarkan jenis situasi ini. Selain ketiga situasi tersebut berikutnya adalah situasi-institusionalisasi. 
Draf bahan ajar matematika ini juga disusun berdasarkan analisis atas respon yang mungkin muncul atas situasi yang dimunculkan. Respon yang muncul bisa sangat beragam, oleh karena itu berdasarkan analisis atas respon yang mungkin muncul disusun pula suatu antisipasi didaktis pedagogis atas respon siswa. Kemudian draf bahan ajar matematika yang telah dikembangkan pada tahap desain kemudian divalidasi oleh ahli dan validator.

1) Validasi ahli

Hasil dari validasi ahli adalah penilaian terhadap perangkat pembelajaran yang sudah dikembangkan dan masukan serta saran terhadap perangkat pembelajaran yang di susun. Selanjutnya dilakukan revisi atas masukan-masukan dan saran tersebut. Hasil penilaian dari validator rata-rata draf bahan ajar matematika berkategori baik. Sedangkan untuk Bahan Ajar yang dikembangkan juga dinyatakan valid kategori baik

2) Revisi produk

Data validasi oleh dosen ahli yang telah diperoleh selanjutnya dianalisis dan dilakukan revisi. Revisi produk pada tahap ini merupakan pengembangan berdasarkan validasi ahli. Hasil revisi produk inilah yang nantinya disebut dengan draft.

d. Tahap Penerapan (Implentation)

Tahap Penerapan adalah tahap melakukan uji coba bahan ajar matematika. Hasil dari tahap implementasi adalah data hasil observasi keterlaksanaan proses perkuliahan menggunakan draf bahan ajar matematika berbasi didactical design research (DDR) dan hasil tes pedagogical conten knowledge (PCK). Data hasil observasi keterlaksanaan proses perkuliahan digunakan untuk mengetahui kepraktisan draf bahan ajar yang dikembangkan. Sedangkan data hasil tes pedagogical conten knowledge (PCK) digunakan untuk mengetahui keefektifan bahan ajar matematika berbasis pendekatan saintifik yang digunakan. Uji coba yang dilakukan adalah uji coba lapangan yang dilaksanakan pada perkuliahan kapita selekta matematika untuk menguji kualitas produk pengembangan yang dilaksankan pada Prodi Pendidikan Matematika FKIP Universitas Majalengka.

e. Tahap Evaluation

Tahap evaluasi dilakukan berdasarkan hasil uji coba bahan ajar. Hasil dari tahap evaluasi adalah hasil analisis kepraktikan dan keefektifan perangkat pembelajaran yang dikembangkan, serta hasil akhir bahan ajar yang dikembangkan.

1) Analisis data kepraktisan

Kepraktisan perangkat pembelajaran ditinjau berdasarkan hasil observasi keterlaksanaan pembelajaran. Berdasarkan data hasil lembar observasi di peroleh total rata-rata skor untuk RPS 4,43 dengan kategori sangat baik, total rata-rata skor untuk bahan ajar adalah 4,33 dengan kategori sangat baik. Dengan demikian ini menunjukan bahwa bahan ajar yang dikembangkan telah praktis dengan kategori sangat baik. Selain itu, aspek kepraktisan perangkat pembelajaran juga dilihat berdasarkan hasil observasi keterlaksanaan pembelajaran sebesar adalah $93,73 \%$. Hal ini menunjukan bahwa perangkat pembelajaran yang dikembangkan telah memenuhi aspek praktis.

2) Analisis data keefektifan

Adapun keefektifan perangkat pembelajaran ditinjau dari hasil tes kemampuan pemecahan masalah matematika siswa. Hasil tes kemampuan pedagogical content knowledge mahasiswa diperoleh persentase ketuntasan mencapai $87,46 \%$. Hal ini menunjukan bahwa bahan ajar telah memenuhi aspek efektif ditinjau hasil uji pedagogical content knowledge.

2. Hasil Uji Coba Produk

a. Validasi Ahli

Validasi bahan ajar pada penelitian ini dilakukan dengan cara menyerahkan produk pengembangan kepada ahli untuk diperiksa dan diberi skor berkaitan dengan kevalidan produk 
pengembangan. Penilaian perangkat pembelajaran yang di kembangkan dilakukan oleh beberapa validator yang terdiri dari ahli didactical design research (DDR), ahli materi, ahli media, dan guru. Secara rinci, hasil penilaian RPS dari masing-masing validator dapat dilihat pada tabel di bawah ini.

Tabel 2. Hasil Penilaian RPS

\begin{tabular}{llll}
\hline No & Validator & RPS & \\
& & Skor & Kategori \\
\hline 1 & Pertama & 4,55 & Sangat Baik \\
2 & Kedua & 4,75 & Sangat Baik \\
& Rata-rata & 4,65 & Sangat Baik \\
\hline
\end{tabular}

Adapun hasil penilaian bahan ajar dari masing-masing validator dapat dilihat pada tabel di bawah ini:

Tabel 3. Hasil Penilaian Bahan Ajar

\begin{tabular}{llll}
\hline No & Validator & RPS & \\
& & Skor & Kategori \\
\hline 1 & Pertama & 4,42 & Sangat Baik \\
2 & Kedua & 4,57 & Sangat Baik \\
& Rata-rata & 4,50 & Sangat Baik \\
\hline
\end{tabular}

Berdasarkan hasil penilaian bahan ajar di atas terlihat bahwa baik RPS maupun bahan ajar yang dikembangkan ada kategori sangat baik. Hal ini menunjukkan bahwa pengembangan bahan ajar berbasis didactical design research (DDR) yang dihasilkan valid sehingga layak diujicobakan di lapangan. Kevalidan perangkat pembelajaran juga terlihat pada setiap aspeknya. Kevalidan RPS untuk setiap aspeknya dapat lihat pada tabel yang disajikan di bawah ini.

Tabel 4. Hasil Analisis Kevalidan RPS Tiap Aspek

\begin{tabular}{llll}
\hline No. & Aspek & Skor & Kategori \\
\hline 1 & Nama Mata Kuliah & 4,80 & Sangat Baik \\
2 & Capaian Pembelajaran & 4,50 & Sangat Baik \\
3 & Pemilihan Materi & 4,45 & Sangat Baik \\
4 & Pemilihan Strategi Pembelajaran & 4,50 & Sangat Baik \\
5 & Kegiatan Pembelajaran & 4,55 & Sangat Baik \\
& Berdasarkan Theory Didactical & & \\
& Situation (TDS) & & \\
6 & Penilain & 4,60 & Sangat Baik \\
\hline
\end{tabular}

Adapun kevalidan bahan ajar untuk setiap aspeknya dapat lihat pada tabel yang disajikan di bawah ini:

Tabel 5. Hasil Analisis Kevalidan Bahan Ajar Tiap Aspek

\begin{tabular}{llll}
\hline No. & Aspek & Skor & Kategori \\
\hline 1 & Kualitas materi bahan ajar & 4,40 & Sangat Baik \\
2 & $\begin{array}{l}\text { Kesesuain bahan ajar yang } \\
\text { dikembangkan }\end{array}$ & 4,50 & Sangat Baik \\
& $\begin{array}{l}\text { keadaan mahasiswa } \\
\text { Kesesuaian bahan ajar dengan } \\
\text { syarat didaktik }\end{array}$ & 4,35 & Sangat Baik \\
& &
\end{tabular}


$4 \quad$ Kesesuaian bahan ajar dengan $\quad 4,35 \quad$ Sangat Baik

syarat konstruksi

b. Uji Coba Lapangan

Uji coba lapangan dilakukan untuk memperoleh data kepraktisan dan keefektifan bahan ajar. Kepraktisan perangkat pembelajaran diperoleh dari data hasil observasi keterlaksanaan pembelajaran, penilaian siswa dan penilaian guru. Ada pun keefektifan perangkat pembelajaran diperoleh dari hasil tes kemampuan pemecahan masalah siswa.

1) Analisis Data Kepraktisan Perangkat Pembelajaran

[1] Analisis hasil Observasi Keterlaksanaan Pembelajaran

Data hasil observasi keterlaksanaan pembelajaran digunakan untuk mengetahui keterlaksanaan langkah-langkah pembelajaran matematika pada materi pertidaksamaan kuadrat. Lembar observasi keterlaksanaan pembelajaran disusun berdasarkan RPS yang telah di kembangkan. Pengambilan data hasil observasi dilakukan sebanyak lima kali pertemuan. Data hasil observasi dapat dilihat pada tabel berikut ini:

Tabel 6. Hasil Observasi Keterlaksanaan Pembelajaran

\begin{tabular}{cc}
\hline Pertemuan Ke & Persentase Keterlaksanaan \\
\hline 1 & $68,41 \%$ \\
2 & $78,95 \%$ \\
3 & $85,21 \%$ \\
4 & $90 \%$ \\
5 & $93 \%$ \\
\hline
\end{tabular}

Dari tabel di atas dapat dilihat observasi pembelajaran mengalami peningkatan persentase keterlaksanaan pembelajaran. Pada pertemuan kelima, persentase keterlaksanaan pembelajaran mencapai persentase sebesar 93\% atau lebih dari 85\%. Dengan demikian berdasarkan hasil analisis tersebut, perangkat pembelajaran telah memenuhi aspek praktis dilihat berdasarkan hasil observasi proses pembelajaran.

2) Revisi Produk

Revisi bahan ajar dilakukan sebanyak dua kali yaitu revisi pada tahap validasi dan revisi pada tahap uji coba lapangan. Adapun rinciannya adalah sebagai berikut:

a) Revisi Produk Setelah Validasi Untuk RPS beberapa saran yang diberikan oleh validator adalah sebagai berikut:

[1] Tahapan proses theory didactical situation (TDS) harus terlihat jelas pada kegiatan.

[2] Masih terdapat beberapa kata yang belum baku.

[3] Variabel terkait sebaiknya dicantumkan dalam RPS.

[4] Tujuan pembelajaran sebaiknya dituliskan serinci mungkin dan jangan digabung.

b) Adapun untuk LKS beberapa saran yang diberikan oleh validator adalah sebagai berikut:

[1] Menuliskan sumber gambar yang ada pada bahan ajar.

[2] Tambahkan kata-kata yang mempermudah untuk membantu siswa memahami maksud dari gambar atau simbol yang terdapat didalam bahan ajar

[3] Memperbaiki tanda baca.

[4] Memperbaiki tata bahasa dengan baik dan benar.

[5] Memperbaiki keruntutan dan kejelasan materi.

[6] Beberapa soal masih menggunakan soal rutin

c) Revisi Produk setelah Uji Coba Lapangan 
Berdasarkan hasil analisis dan uji coba lapangan dinyatakan bahwa bahan ajar yang dikembangkan telah memenuhi aspek praktis dan efektif.

d) Analisis Data

Keefektifan Perangkat Pembelajaran Keefektifan perangkat pembelajaran dalam penelitian ini ditinjau dari hasil tes pedagogical content knowledge. Tes ini diberikan setelah penerapan perangkat pembelajaran selesai dilaksanakan.

Tabel 7. Rekapitulasi hasil tes kemampuan pemecahan masalah

\begin{tabular}{lll}
\hline No. & Uaraian & Skor \\
\hline 1 & Rata-rata & 79,05 \\
2 & Nilai tertinggi & 94.00 \\
3 & Nilai terendah & 55.00 \\
4 & Siswa yang tuntas & 23 \\
5 & Siswa yang tidak tuntas & 3 \\
& Persentase Ketuntasan & $89,01 \%$ \\
\hline
\end{tabular}

Berdasarkan data yang disajikan tabel di atas, rata-rata hasil tes kemampuan pemecahan masalah siswa sebesar 79,05 dengan banyak siswa yang tuntas adalah 23 orang sehingga persentase ketuntasannya sebesar $89,01 \%$. Dengan demikian persentase ketuntasan yang dicapai telah melebihi $80 \%$ sehingga dapat disimpulkan bahan ajar yang dikembangkan telah memenuhi kriteria efektif.

Berdasarkan temuan diperoleh beberapa learning obstacles yang ditemukan bersifat epistemological, ontogenical, dan didactical (Brousseau, 2006; Suryadi, 2013). Epistemological Obstacles yang ditemukan yaitu generalisasi. Proses generalisasi pengetahuan tertentu pada konteks lain, yaitu: (1) generalisasi persamaan terhadap pertidaksamaan (mengalikan pertidaksamaan kuadrat dengan bilangan negatif siswa tidak mengubah tanda pertidaksamaan, siswa melihatnya proses yang sama pada persamaan dan memaknai proses pertidaksamaan kuadrat sama dengan proses pengerjaan persamaan kuadrat); (2) generalisasi pertidaksamaan dua variabel ke pertidaksaman kuadrat (siswa salah melihat hubungan representasi grafik dengan penyelesaian pertidaksamaan kuadrat). Bahwa generalisasi mahasiswa Pendidikan matematika berada pada kategori rendah dalam beberapa tahapan generalisasi (Ramdhani, 2018). Hal ini menunjukkan bahwa kesalahan yang dibuat dalam menjawab pertanyaan bukan tidak memiliki pengetahuan, tetapi pengetahuan yang digunakan tidak tepat pada konteks tersebut. Selanjutnya Obstacles khususnya epistemological obstacles yang ditemukan dari hasil penelitian ini pun, menunjukkan bahwa kesalahan yang dilakukan diakibatkan penggunaan pengetahuan persamaan yang tepat pada konteks persamaan, ke konteks pertidaksamaan kuadrat. Kesalahan yang diakibatkan siswa melakukan generalisasi konsep persamaan ke konteks pertidaksamaan kuadrat. Didactical obstacles yang ditemukan yaitu hambatan yang dikarenakan pembelajaran pertidaksamaan kuadrat yang diberikan hanya mengajarkan mengenai manipulasi aljabar dan metode garis bilangan dan pembelajaran tidak menekankan perbedaan persamaan dan pertidaksamaan (tidak ada transisi yang jelas dari persamaan ke pertidaksamaan). Hal ini menunjukkan keterbatasan pilihan didaktis yang digunakan guru. Keterbatasan pilihan inilah yang mengakibatkan tidak memiliki pengetahuan akan konsep pertidaksamaan secara utuh. Sebagai mana telah dijelaskan sebelumnya bahwa produk yang dikembangkan dalam penelitian ini berupa berupa bahan ajar matematika berbasis didactical design research (DDR) berorientasi pada peningkatan pedagogical content knowledge calon guru matematika. Bahan ajar pembelajaran yang dikembangkan meliputi Rencana Pembelajaran Semester (RPS) dan Bahan Ajar dengan pendekatan saintifik yang berorientasi pada kemampuan pemecahan masalah. Langkah-langkah pengembangan yang digunakan mengadaptasi dari model ADDIE yang dikembangkan oleh Dick and Carry (Gall et al., 2014). Model pengembangan ADDIE terdiri dari lima tahap, yaitu: Analysis, Design, Development, 
Implementation, dan Evaluation. Tahapan-tahapan ini dimaksudkan agar peneliti mengetahui kualitas dari bahan ajar yang dikembangkan yang harus memenuhi aspek valid, praktis, dan efektif. 1. Kevalidan perangkat pembelajaran dilakukan oleh validator ahli kurikulum, materi, dan media. Hasil penilaian dari validator diperoleh rata-rata skor kevalidan perangkat pembelajaran berupa RPS adalah 4,65 dengan kategori sangat baik. Sedangkan untuk bahan ajar yang dikembangkan juga dinyatakan valid dengan rata-rata skor 4,50 juga dengan kategori sangat baik. 2. Kepraktisan Perangkat Pembelajaran Penilaian kepraktisan perangkat pembelajaran matematika berbasis pendekatan saintifik berorientasi pada kemampuan pemecahan masalah matematika diperoleh dari hasil angket kepraktisan produk oleh guru dan siswa, serta observasi pembelajaran di dalam kelas. Berdasarkan observasi pembelajaran dengan pendekatan saintifik mengalami peningkatan persentase keterlaksanaan pembelajaran. Pada pertemuan kelima, persentase keterlaksanaan pembelajaran mencapai persentase sebesar 93\% atau lebih dari $85 \%$. Dengan demikian berdasarkan hasil analisis tersebut, perangkat pembelajaran telah memenuhi aspek praktis dilihat berdasarkan hasil observasi proses pembelajaran. Keefektifan Perangkat Pembelajaran Penilaian Keefektifan perangkat pembelajaran matematika berbasis pendekatan saintifik berorientasi pada kemampuan pemecahan masalah matematika ditinjau berdasarkan tes kemampuan pemecahan masalah matematika yang diberikan setelah dilaksanakan penerapan perangkat yang dikembangkan. Berdasarkan pedagogical content knowledge diperoleh rata-rata hasil tes kemampuan pemecahan masalah siswa sebesar 79,05 dengan banyak siswa yang tuntas adalah 23 orang sehingga persentase ketuntasannya sebesar 89,01\%. Dengan demikian persentase ketuntasan yang dicapai telah melebihi $80 \%$ sehingga dapat disimpulkan bahan ajar yang dikembangkan telah memenuhi kriteria efektif.

\section{Kesimpulan}

Pertidaksamaan merupakan salah satu topik penting yang digunakan untuk memahami beragam topik dalam matematika. Temuan terkait dengan Ontogenical obstacle berdasarkan analisis data tes dan wawancara diperoleh ontogenical obstacle yaitu arithmatic thinking. Mahasiswa belum secara utuh belum bisa menjelaskan transisi dari aritmatika ke aljabar. Epistemological obstacles yaitu terdapat kesalahan dalam pengerjaan soal pertidaksamaan kuadrat karena melakukan generalisasi persamaan ke pertidaksamaan baik representasi maupun proses yaitu ketika mengalikan pertidaksamaan kuadrat dengan bilangan negatif siswa tidak mengubah tanda pertidaksamaan, siswa melihatnya proses yang sama pada persamaan. Didactical obstacles temuan terkait dengan representasi dan pendekatan yang diberikan oleh mahasiswa tidak beragam dan hanya terpaku pada metode garis bilangan dan mahasiswa tidak secara jelas perbedaan persamaan dan pertidaksamaan (tidak ada transisi yang jelas dari persamaan ke pertidaksamaan). Bahan ajar yang dikembangkan telah memenuhi kriteria valid. Hal ini didasarkan penilaian yang dilakukan oleh dua orang pakar, di mana diperoleh dengan kriteria sangat baik. Bahan ajar yang dikembangkan telah memenuhi kriteria praktis. Kepraktisan bahan ajar terlihat dari hasil respon siswa terhadap bahan ajar yang memperoleh kriteria sangat baik. Bahan ajar yang dikembangkan telah memenuhi kriteria efektif. Keefektifan bahan ajar terlihat berdasarkan hasil tes kemampuan pemecahan masalah matematika yang mencapai persentase ketuntasan sebesar 89,01\%. Berdasarkan beberapa hasil temuan, penulis memberikan saran bagi yang akan melakukan penelitian pengembangan bahan ajar disarankan untuk lebih banyak melakukan untuk lebih banyak mengkaji beberap sumber agar bahan referensi mencukupi dan variative.

\section{Daftar Pustaka}

Argyle, M. (2013). The psychology of happiness. Routledge.

Blömeke, S., Kaiser, G., König, J., \& Jentsch, A. (2020). Profiles of mathematics teachers' competence and their relation to instructional quality. ZDM, 1-14. https://doi.org/10.1007/s11858-02001128-y

Brousseau, G. (2006). Theory of didactical situations in mathematics: Didactique des mathématiques, 1970--1990 
(Vol. 19). Springer Science \& Business Media.

Carvalho, G. S., Silva, R., Lima, N., Coquet, E., \& Clément, P. (2004). Portuguese primary school children's conceptions about digestion: identification of learning obstacles. International Journal of Science Education, 26(9), 1111-1130. https://www.researchgate.net/profile/Graca_Carvalho2/publication/233613948_Portuguese_pr imary_school_children $\% 27$ s_conceptions_about_digestion_Identification_of_learning_obstacles /links/55327a460cf2f2a588af9e81/Portuguese-primary-school-childrens-conceptio

Clément, P. (2003). Situated conceptions and obstacles. The example of digestion/excretion. In Science education research in the knowledge-based society (pp. 89-97). Springer. https://doi.org/10.1007/97894-017-0165-5_10

Conner, K., Webel, C., \& Zhao, W. (2017). Towards a Hypothetical Learning Trajectory for Questioning. North American Chapter of the International Group for the Psychology of Mathematics Education.

Empson, S. B. (2011). On the idea of learning trajectories: Promises and pitfalls. The Mathematics Enthusiast, 8(3), 571-596.

Ernest, P. (2015). The social outcomes of learning mathematics: Standard, unintended or visionary? International Journal of Education in Mathematics Science and Technology, 3(3), 187-192. https://www.ijemst.net/index.php/ijemst/article/view/62

Fuadiah, N. F. (2017). Hypothetical Learning Trajectory pada Pembelajaran Bilangan Negatif Berdasarkan Teori Situasi Didaktis di Sekolah Menengah. Mosharafa: Jurnal Pendidikan Matematika, 6(1), 13-24.

Gall, M. D., Gall, J. P., \& Borg, W. R. (2014). Applying educational research: How to read, do, and use research to solve problems of practice. Pearson Higher Ed.

Gess-Newsome, J., Taylor, J. A., Carlson, J., Gardner, A. L., Wilson, C. D., \& Stuhlsatz, M. A. M. (2019). Teacher pedagogical content knowledge, practice, and student achievement. International Journal of Science Education, 41(7), 944-963. https://doi.org/10.1080/09500693.2016.1265158

Gudmundsdottir, S., \& Shulman, L. (1987). Pedagogical content knowledge in social studies. Scandinavian Journal of Educationl Research, 31(2), 59-70. https:/ / doi.org/10.1080/0031383870310201

Hannula, J. (2017). Subject matter knowledge and pedagogical content knowledge in the learning diaries of prospective mathematics teachers.

Herold, F. (2019). Shulman, or Shulman and Shulman? How communities and contexts affect the development of pre-service teachers' subject knowledge. Teacher Development, 23(4), 488-505. https://doi.org/10.1080/13664530.2019.1637773

Ilanlou, M., \& Zand, M. (2011). Professional competencies of teachers and the qualitative evaluation. Procedia-Social and Behavioral Sciences, 29, 1143-1150.

Jatisunda, M. G. (2019). Kesulitan Siswa dalam Memahami Konsep Trigonometri di lihat dari Learning Obstacles. Didactical Mathematics, 2(1), 9-16.

Kansanen, P., \& Meri, M. (1999). The didactic relation in the teaching-studying-learning process. Didaktik/Fachdidaktik as Science (-s) of the Teaching Profession, 2(1), 107-116. https://www.researchgate.net/profile/Brian_Hudson5/publication/284365075_DidaktikFachdi daktik_as_the_Science-

s_of_the_Teaching_Profession/links/56522cfb08ae1ef92975650d/Didaktik-Fachdidaktik-asthe-Science-s-of-the-Teaching-Profession.pdf\#page $=113$

Lestarai, U. (2019). Analisis Learning Obstacle Pada Pembelajaran Nilai Tempat Siswa Kelas II SD [Learning Obstacle Analysis on Place Value Learning in Students Class II Elementary School]. PED AGOGIA: Jurnal Pendidikan, 8(1), 61-68.

Loughran, J. (2005). Researching teaching about teaching: Self-study of teacher education practices. 
Studying Teacher Education, 1(1), 5-16. https://doi.org/10.1080/17425960500039777

Maher, C. A., Sigley, R., Sullivan, P., \& Wilkinson, L. C. (2018). An international perspective on knowledge in teaching mathematics. The Journal of Mathematical Behavior, 51, 71-79.

Muruganantham, G. (2015). Developing of E-content package by using ADDIE model. International Journal of Applied Research, 1(3), 52-54.

Muslim, S. R., Mulyani, E., \& Prabawati, M. N. (2017). Kajian Learning Obstacle Mahasiswa Pendidikan Matematika pada Materi Trigonometri dalam Perkuliahan Kapita Selekta Sekolah Menengah. Jurnal Siliwangi Seri Pendidikan, 3(2).

Perbowo, K. S., \& Anjarwati, R. (2017). Analysis Of Students'learning Obstacles On Learning Invers Function Material. Infinity Journal, 6(2), 169-176. https:// doi.org/10.22460/infinity.v6i2.p169-176

Ramdhani, S. (2018). Kemampuan generalisasi mahasiswa pada perkuliahan kapita selekta matematika sma. Jurnal Analisa, 4(2), 83-89.

Shulman, L. (1987). Knowledge and teaching: Foundations of the new reform. Harvard Educational Review, 57(1), 1-23. https://doi.org/10.17763/haer.57.1.j463w79r56455411

Subanji, S. (2015). Peningkatan Pedagogical Content Knowledge Guru Matematika Dan Praktiknya Dalam Pembelajaran Melalui Model Pelatihan Teqip. Jurnal Ilmu Pendidikan Universitas Negeri Malang, 21(1), 106225.

Sukaesih, S., Ridlo, S., \& Saptono, S. (2017). Profil kemampuan pedagogical content knowledge (PCK) calon guru biologi. Lembaran Ilmu Kependidikan, 46(2), 68-74.

Suryadi, D. (2010). Menciptakan proses belajar aktif: Kajian dari sudut pandang teori belajar dan teori didaktik. Bandung: Tidak Diterbitkan.

Suryadi, D. (2013). Didactical design research (DDR) dalam pengembangan pembelajaran matematika. Prosiding Seminar Nasional Matematika Dan Pendidikan Matematika, 1, 3-12. http://www.academia.edu/download/55599800/SEMNAS-PMAT-

2013_Jurnal_Didi_Suryadi_DDR.pdf\#page=13 